López-Garro, A., \& Zanella, I. (2021). Residency of bull sharks, Carcharhinus leucas (Carcharhiniformes: Carcharhinidae), at San Pedrillo Islet in Islas Murciélago, North Pacific of Costa Rica. Revista de Biología Tropical, 69(Suppl. 2), S246-S255. https://doi.org/10.15517/rbt.v69iS2.48321

Biologín Tropical

https://doi.org/10.15517/rbt.v69iS2.48321

\title{
Residency of bull sharks, Carcharhinus leucas \\ (Carcharhiniformes: Carcharhinidae), at San Pedrillo Islet in Islas Murciélago, North Pacific of Costa Rica
}

Andrés López-Garro'; (D) https://orcid.org/0000-0001-7834-5306

Ilena Zanella ${ }^{1}$; (D) https://orcid.org/0000-0002-3820-7643

1. Asociación Conservacionista Misión Tiburón, Playas del Coco, Guanacaste, Costa Rica; alopez@misiontiburon.org, izanella@misiontiburon.org

Received 21-XII-2020. Corrected 08-II-2021. Accepted 05-V-2021.

\begin{abstract}
Introduction: The bull shark, Carcharhinus leucas, is particularly vulnerable to anthropogenic actions because of its permanence in coastal ecosystems; populations depletion is registered in different places around the world. Aggregations of bull sharks have been reported in the North Pacific of Costa Rica, at Islas Murciélago, within the Guanacaste Conservation Area.

Objective: To study the residency of bull sharks at San Pedrillo islet, Islas Murciélago.

Methods: During the study period (June 2013 to February 2015) we used passive telemetry to tag 10 bull sharks. Results: All the sharks tagged were females, they were detected on 59798 occasions by the acoustic receiver deployed in San Pedrillo. Acoustic signals from tagged sharks were received for a total period of 1 to 229 days (mean $=73.9 \pm 71.3$ days), with the last detections occurring on 9 January 2015. The Residency Index for each tagged shark across the entire monitoring period ranged from 0.41 to 1.00 . The bull shark activity showed a significant pattern throughout the day at the receiver that specifically corresponded with the daily light cycle. Conclusions: This study concludes that San Pedrillo is an aggregation site (cleaning station) for bull sharks $(C$. leucas), possibly related to reproduction and not feeding behaviors.
\end{abstract}

Key words: Carcharhinus leucas; Guanacaste; tagging; acoustic telemetry; aggregation site.

The Archipelago of Islas Murciélago is part of the Marine Sector of the Guanacaste Conservation Area, in the north Pacific of Costa Rica. One of the top predators of this area is the bull shark, Carcharhinus leucas (Valenciennes 1839), which is a cosmopolitan tropical and subtropical species commonly found in coastal ecosystems such as estuaries, lagoons, and river mouths thanks to their capacity to enter freshwater systems (Compagno, 1984). Like other elasmobranchs, the bull shark uses estuaries and river mouths as nurseries. The fact that these systems are also of high productivity could be one of the reasons why adult female bull sharks prefer these sites to give birth (Curtis, Parkyn, \& Burgess, 2013). Several authors have reported bull sharks using coastal ecosystems for protection and food during their early life stages (Simpfendorfer, Greitas, Wiley, \& Heupel, 2005; Werry \& Clua, 2013). Nursery grounds for bull sharks have been documented in the Gulf of Mexico 
and the east coast of Florida (Curtis, Adams, \& Burgess, 2011). Bull shark juveniles can access rivers to feed, preying on species that migrate between rivers and oceans during tidal changes. Numerous studies have also reported the preference or habitat fidelity of adult bull sharks to shallow waters of coastal habitats, particularly to those with a high input of freshwater, such as river mouths and estuaries (Bangley, Paramore, Shifman, \& Rulifson, 2018; Brunnschweiler, Queiroz, \& Sims, 2010; Carlson, Ribera, Conrath, Heupel, \& Burgess, 2010; Graham et al., 2016; Heupel et al., 2015). The permanence of bull sharks in coastal ecosystems makes them vulnerable to anthropogenic actions like habitat degradation, pollution, and fishing exploitation (Curtis et al., 2013; Thorson, 1971; Werry \& Clua, 2013).

Bull shark population depletion is reported in different places around the world, such as the Gulf of Mexico and the southwest Atlantic of Brazil (Almeida, McGrath, \& Ruffino, 2001; Powers et al., 2013). In Central America, specifically in Lake Nicaragua, exploitation of bull sharks started in the 1960s, when they were consumed domestically and exported overseas (Thorson, 1982). In the 1970s an Asiatic shark fin processing plant started to operate near Granada. In Lake Nicaragua, the bull shark fishery industry collapsed in the 1980s, yet the population has still not recovered from overexploitation (McDavitt, 2002).

Bull sharks currently have a higher economic value as a tourist resource, related to recreational diving, than as a commercial species. For example, at Cabo Pulmo National Park (CPNP), Mexico, the bull shark is one of the main attractions for tourists. According to Pasos-Acuña (2018), bull shark recreational diving at CPNP represents more than $\$ 7.5$ million each year. Worldwide, it is estimated that half a million people are interested in shark diving, generating more than US\$314 million per year and more than 10000 jobs. Furthermore, it is expected that in the next 20 years shark tourism is going to double at a global scale, potentially generating more than US\$750 million annually (Cisneros, Barnes, Navarro, \& Rashidsumaila, 2013).

In Costa Rica, bull shark juveniles and adults are occasionally caught by artisanal fishermen (bottom line and gill nets) who fish close to river mouths and estuaries (López, Arauz, Zanella, \& Le Foulge, 2009; López \& Zanella, 2015). The exploitation of bull sharks in Costa Rica has been developed without any specific management regulation. The San Pedrillo islet, located at Islas Murciélago archipelago, has been identified empirically as an aggregation site for bull sharks, the only one reported for the species in Costa Rica. During the rainy season (May-November), local communities such as Playas del Coco, Tamarindo, and Cuajiniquil, directly benefit from SCUBA diving with bull sharks in a completely natural environment (Davis \& Klapfer, 2018). In this study, we used acoustic telemetry to monitor the residence of adult bull sharks at the San Pedrillo islet. This study will add new information for the design of conservation strategies to improve the protection of the bull shark population at the Conservation Area of Guanacaste and surrounding areas.

\section{MATERIALS AND METHODS}

Study area: The archipelago of Islas Murciélago is located in the north Pacific of Costa Rica, $5 \mathrm{~km}$ off mainland Costa Rica, and is comprised of five islands and ten islets, one of them being San Pedrillo (1051'12.4'N \& $85^{\circ} 57^{\prime} 32.5^{\prime}$ W) (Denyer, Cortés, \& Cárdenes, 2005). As part of the Área de Conservación Guanacaste (ACG, Guanacaste Conservation Area), the Islas Murciélago belong to a UNESCO World Heritage Site; part of the Sistema Nacional de Áras de Conservación (SINAC, National System of Conservation Areas of Costa Rica) from the Ministry of Environment of Costa Rica (SINAC, 2013). The archipelago is a no-take Marine Protected Area with an extension of 43,000 ha where only tourism activities are allowed. The marine biodiversity of Islas Murciélago is influenced by a seasonal upwelling (from December to March) that rises 
cold deep water masses that generate an intense effect on the distribution of nutrients and plankton (Jiménez, 2016; Rodríguez, Alfaro, \& Cortés, 2021).

Acoustic array and shark tagging: Tagging was performed between June 2013 and September 2014 at San Pedrillo islet between 18 and $30 \mathrm{~m}$ depth, where the aggregation of adult bull sharks is known to occur (Davis \& Klapfer, 2018). An acoustic receiver was deployed at the same site using SCUBA gear. The tags or acoustic transmitters were V16-4H with external cases (Vemco Ltd., Halifax, Nova Scotia, Canada), which were tethered to stainless steel darts. Scuba divers inserted the darts into the muscle of the bull sharks at the base of the first dorsal fin. The researchers reported the sex of each shark tagged (presence or absence of claspers) and estimated the size (total length) of the shark. The sharks were tagged during the rainy season when the upwelling is not occurring and ocean conditions favor diving activities and underwater tagging. Transmitters were set to be silent (delay) for a randomized period of 40 to $140 \mathrm{~s}$ between each pulse train and had a battery life of approximately 4 years. Each transmitter tag conveyed a specific code for an individual shark, and periodically emitted a pulse train of closely spaced $69 \mathrm{kHz}$ pings detected by the receiver VR2W (Vemco Ltd., Halifax, Nova Scotia, Canada), which was deployed before tagging on the 12th of June 2013. The receiver was placed at a depth of 30-35 $\mathrm{m}$ in a sandy bottom close to the aggregation site, next to the San Pedrillo islet. The receiver was anchored on a $65 \mathrm{~kg}$ cement block attached to a stainless-steel cable and suspended in the water column (approximately $3-5 \mathrm{~m}$ from the bottom) with a buoy. The receiver stored the information emitted from the transmitters (date, time of the detection, and transmitter number for each individual pulse train) along a $250-300 \mathrm{~m}$ radius, verified via range tests. The detection of the tags decreased abruptly after $250 \mathrm{~m}$, and tags were not detected at distances greater than $300 \mathrm{~m}$. Receiver data was downloaded approximately every 5 months, for 1.5 years (June 2013 to February 2015).

Data analysis: The data recorded by the acoustic receiver in San Pedrillo was downloaded using the software VUE version 2.0.6. Shark detections during the study period were plotted using the 'ggplot' package in $\mathrm{R}$ version 3.6.3 (R Development Core Team R, 2014). To determine whether an individual was present on any day close to the receiver, we set a minimum of three detections as a metric. The detections were compared: a) between individuals using the no-parametric test Kruskall Wallis; b) between months of the rainy season (May-November) and months of the dry season (December-April) using the no-parametric test Wilcoxon (Infostat, 2008). The Residency Index (RI) was further calculated for each bull shark tagged to better examine occurrence patterns across the array. RI was defined as the number of days a bull shark was detected within the receiver array, divided by the number of days monitored (i.e. number of days from the tagging date to the last date detections were received for all transmitters) (Espinoza, Farrugia, \& Lowe, 2011; Papastamatiou, Friedlander, Caselle, \& Lowe, 2010; Zanella, López, \& Cure, 2019); RI values range from 0 to 1 , with a value of 1 indicating the highest possible residency at the receiver array. The average number of detections per individual tagged shark throughout a daily cycle was plotted using 'ggplot' and 'plyr' packages in R version 3.6.3 (R Development Core Team R, 2014). The environmental variables of Sea Surface Temperature, SST $\left({ }^{\circ} \mathrm{C}\right)$ and Chlorophyll- $\alpha$ concentrations $\left(\mathrm{mg} / \mathrm{m}^{3}\right)$ were downloaded from NASA's OceanColor platform (www.oceancolor.nasa.org), with a resolution of $4 \mathrm{~km}$, whose source is the National Oceanic and Atmospheric Administration (NOAA). Those files were downloaded in HDF format. Data was downloaded monthly from June 2013 to February 2015. Processed data was exported as an ASCII file using the QGIS and DIVAGIS software, these layers were used to extract the information from at least 6 points around the 
Islas Murcielago, to an optimal representation of the area. Residual normality test (Shapiro) and homoscedasticity of variances test (Levene) were conducted. Since data was normal and homoscedastic, comparisons were made between seasons of the year (dry and rainy) with paired t-student tests, performed with 95 $\%$ confidence (Infostat, 2008). We compared the detections of tagged sharks at the receiver between day (06:00-17:00) and night hours (18:00-5:00), using the Wilcoxon nonparametric test (Infostat, 2008), and we described the average number of detections per individual tagged shark at the receiver throughout a daily cycle.

Research Permit: All the activities related to this study were done in compliance with the resolution of scientific permits $\mathrm{N}^{\circ}$ ACGPI-004-2013, No ACG-PI-017-2014 and $\mathrm{N}^{\mathrm{o}}$ ACG-PI-030-2015. Such permits were authorized by the Área de Conservación Guanacaste (ACG, Guanacaste Conservation Area) of the SINAC, Ministry of Environment of Costa Rica.

\section{RESULTS}

Between June 2013 and September 2014, we tagged ten adult female bull sharks (C. leucas) at San Pedrillo, Islas Murciélago. Based on the approximate size of the individuals ( $>2 \mathrm{~m}$ total length) we classified them as "adults" following the maturity size estimation determined in the Gulf of México and Northern Brazil (Cruz-Martínez, Chiappa-Carrara, \& ArenasFuentes, 2004; Niella, Afonso, \& Hazin, 2017). During the study period (June 2013 to February 2015) a total of 59,798 detections were recorded by the acoustic receiver. Acoustic signals from tagged sharks were received for a total period of 1 to 229 days $($ mean $=73.9 \pm 71.3$ days), with the last detections occurring on 9 January 2015 (Table 1). The number of detections was not significantly different between individuals $(\mathrm{H}=9.00, \mathrm{P}>0.05)$.

The detections of tagged bull sharks recorded in the receiver were higher during the rainy season (May-November) compared with the detections recorded during the dry season (December-April) ( $\mathrm{W}=1593.00, \mathrm{P}<0.05)$, as more than $80 \%$ of the detections were recorded between May and November. The months of July and August together provided almost 50\% of all detections, therefore they are considered the most outstanding months for bull sharks in this area. Even though some sharks were detected during the dry season (DecemberFebruary), less than $20 \%$ of detections were registered for the first months of the year (Fig. 1, Table 2).

TABLE 1

Residency of Carcharhinus leucas monitored in San Pedrillo, Islas Murciélago, Costa Rica. Sex: F=females; Residency Index (RI): the number of days a shark was detected within the receiver array divided by the number of days monitored. All sharks were detected at the receiver

\begin{tabular}{cccccccccc}
\hline Tag \# & Tag ID & $\begin{array}{c}\text { Tagging } \\
\text { date }\end{array}$ & $\begin{array}{c}\text { Last d } \\
\text { etection }\end{array}$ & Sex & $\begin{array}{c}\text { Size } \\
(\mathrm{m})\end{array}$ & $\begin{array}{c}\text { No of } \\
\text { detections }\end{array}$ & $\begin{array}{c}\text { Days } \\
\text { monitored }\end{array}$ & $\begin{array}{c}\text { Days } \\
\text { detected }\end{array}$ & RI \\
\hline 1 & 30322 & $20-06-13$ & $04-02-14$ & F & $>2$ & 16127 & 229 & 193 & 0,84 \\
2 & 58967 & $12-06-14$ & $26-09-14$ & F & $>2$ & 10520 & 75 & 68 & 0,91 \\
3 & 25468 & $27-09-14$ & $09-01-15$ & F & $>2$ & 16804 & 135 & 135 & 1,00 \\
4 & 25466 & $27-09-14$ & $09-01-15$ & F & $>2$ & 5715 & 39 & 59 & 0,44 \\
5 & 58968 & $12-06-14$ & $21-07-14$ & F & $>2$ & 5170 & 48 & 0,85 \\
6 & 25465 & $27-09-14$ & $13-10-14$ & F & $>2$ & 1766 & 25 & 14 & 0,90 \\
7 & 25467 & $15-06-14$ & $10-07-14$ & F & $>2$ & 1744 & 22 & 9 & 0,56 \\
8 & 30321 & $20-06-13$ & $12-07-13$ & F & $>2$ & 1238 & 30 & 28 & 0,41 \\
9 & 30320 & $15-06-14$ & $15-07-14$ & F & $>2$ & 707 & 1 & 0,93 \\
10 & 30319 & $12-06-14$ & $12-06-14$ & F & $>2$ & 7 & & 1 & 1,00 \\
\hline
\end{tabular}


TABLE 2

Average monthly detections of Carcharhinus leucas, Sea Surface Temperature (SST, $\left.{ }^{\circ} \mathrm{C}\right)$ and Chlorophyll- $\alpha$ concentrations $\left(\mathrm{mg} / \mathrm{m}^{3}\right)$ monitored in San Pedrillo, Islas Murciélago, Costa Rica

\begin{tabular}{lccc}
\hline \multicolumn{1}{c}{ Month } & Average of Detections \pm SD & Average of SST $\left({ }^{\circ} \mathrm{C}\right) \pm$ SD & Average of Chlorophyll- $\alpha\left(\mathrm{mg} / \mathrm{m}^{3}\right) \pm \mathrm{SD}$ \\
\hline June & $517.66 \pm 424.15$ & $27.89 \pm 0.01$ & $0.22 \pm 0.08$ \\
July & $2673 \pm 2126.69$ & $28.83 \pm 0.01$ & $0.41 \pm 0.00$ \\
August & $2486.40 \pm 2268.54$ & $29.24 \pm 0.03$ & $0.42 \pm 0.01$ \\
September & $1550 \pm 942.33$ & $29.44 \pm 0.02$ & $0.31 \pm 0.05$ \\
October & $1089.50 \pm 1054.40$ & $28.92 \pm 0.02$ & $0.32 \pm 0.00$ \\
November & $1817.00 \pm 1553.30$ & $28.66 \pm 0.02$ & $0.74 \pm 0.00$ \\
December & $2899.00 \pm 1951.07$ & $27.87 \pm 0.01$ & $1.36 \pm 0.07$ \\
January & $1170.33 \pm 922.91$ & $27.31 \pm 0.01$ & $2.36 \pm 0.03$ \\
Febraury & $5 \pm 0$ & $26.97 \pm 0.18$ & $4.75 \pm 0.03$ \\
March & 0.00 & $28.52 \pm 0,06$ & $0.89 \pm 0,00$ \\
April & 0.00 & $28.35 \pm 0,01$ & $0.65 \pm 0,00$ \\
May & 0.00 & $30.02 \pm 0,37$ & $0.21 \pm 0,06$ \\
\hline
\end{tabular}

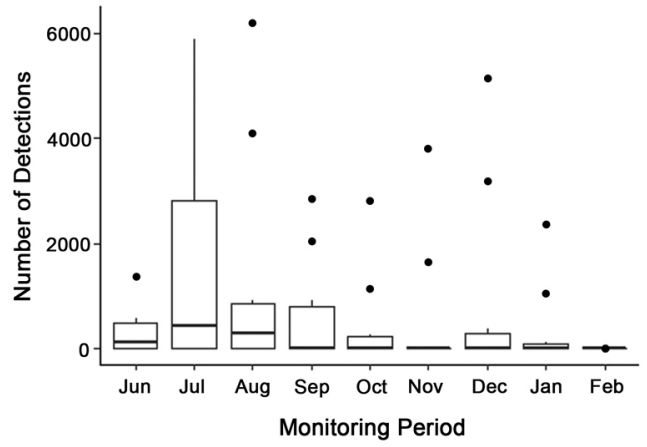

Fig. 1. Number of detections per month of bull sharks (Carcharhinus leucas) tagged at San Pedrillo, Islas Murciélago, ACG, Costa Rica during the study period (June 2013-Febraury 2015).

Regarding environmental variables (SST and Chlorophyll- $\alpha$ concentrations), the temperature was significantly higher during the months of the rainy season compared with the months of the dry season $(\mathrm{t}=8.82, \mathrm{P}<0.0001)$; whereas the Chlorophyll- $\alpha$ concentrations were significantly lower during the months of the rainy season compared with the months of the dry season $(t=-7.79, P<0.0001$; Table 2$)$.

The Residency Index for each tagged shark across the entire monitoring period ranged from 0.41 to 1.00 (Table 1) and there wasn't a clear tendency to monthly variation in residency metrics (Fig. 2). During the time of this study, bull shark activity showed a significant pattern

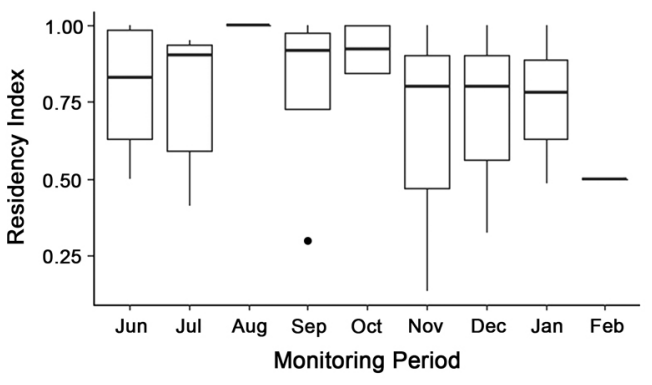

Fig. 2. Residency Index of bull sharks (Carcharhinus leucas) tagged at San Pedrillo, Islas Murciélago, ACG, Costa Rica during the study period (June 2013-Febraury 2015).

throughout the day at the receiver that specifically corresponded with the daily light cycle. Detections were significantly highest from the early morning to late afternoon $(6: 00 \mathrm{~h}$ to $18: 00$ h) $(\mathrm{W}=6862.50, \mathrm{P}<0.0001)$ (Fig. 3).

\section{DISCUSSION}

This study confirmed that adult bull sharks use San Pedrillo as an aggregation site. This islet, located in the Marine Protected Area of the ACG, is a site where bull sharks remain for long periods, especially during the rainy season (May-November), mostly with short absences of 1 to 3 days. Even though some bull sharks visited San Pedrillo during the dry 


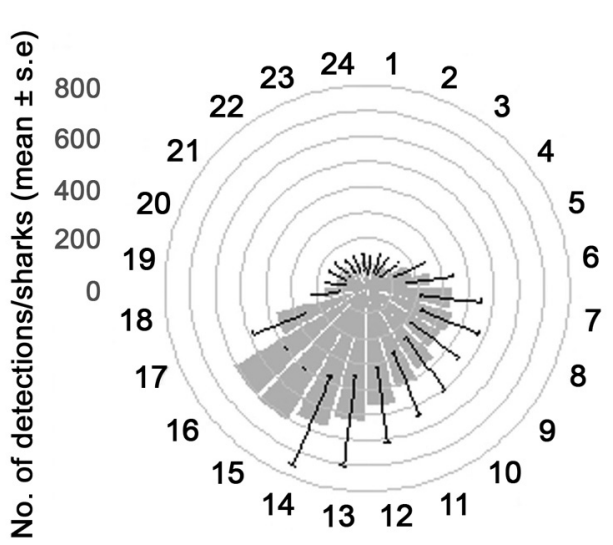

Fig. 3. Average number of detections per individual tagged shark at the receiver throughout a daily cycle, San Pedrillo, Islas Murciélago, Costa Rica, during the study period (June 2013-February 2015).

months, less than $20 \%$ of total detections correspond to December to February. This study also confirmed that during the dry season the marine area around Islas Murcielago experiment a significant decrease of the temperature and a significant increment of Chlorophyll concentration, as a result of the seasonal upwelling reported for the North Pacific of Costa Rica, produced by strong winds from the Caribbean (Jiménez, 2016; Rodríguez et al., 2021). These changes in environmental variables correspond to a significant decrease in the detections of bull sharks in the study area. Such behavior patterns of temporary residence by bull sharks have also been reported in South Africa, Mexico and Fiji, where authors make a close connection between residence and change in water temperature and food availability (Brunnschweiler \& Barnett, 2013; Brunnschweiler, Queiroz, \& Sims, 2010; Daly et al., 2014). Daly et al. (2014) described a site known as "Pinnacle reef" in Mozambique, as an important aggregation site for adult bull sharks who reside there for long periods, mainly during the summer austral months (November-May).

Several studies have reported local migrations of bull sharks, which is correlated to seasonal changes (Daly et al., 2014; Niella, Afonso, \& Hazin, 2017). Satellite tags on bull sharks have revealed important coastal migrations, thus contradicting many theories that this species is sedentary in coastal waters, such is the case in the Gulf of Mexico, where tagged bull sharks covered between 2 to 1500 $\mathrm{km}$ in only 85 days, using primarily temperate shallow waters (>20 m depth) (Carlson et al., 2010). Another example is a male bull shark who covered more than $3000 \mathrm{~km}$ in 75 days, mostly waters $>20 \mathrm{~m}$ depth along the Brazilian coast (Niella, Afonso, \& Hazin, 2017). Similarly, off the coast of Australia, Heupel et al. (2015) described migration patterns of bull sharks with a range greater than $1700 \mathrm{~km}$. Some authors suggest that the Great Barrier Reef plays an important ecological role for adult bull sharks off the east coast of Australia, where sharks move between different coastal habitats primarily in the search for warmer waters.

At San Pedrillo, the lowest number of detections were reported during the night, suggesting that the bull sharks take part in local migrations outside of San Pedrillo, possibly for feeding purposes. The data also revealed that most of the tagged sharks in San Pedrillo made daily migrations during the entire study period. Such results can be compared to other studies like the one off the east coast of Africa (Daly et al., 2014), which showed bull sharks' loyalty to "Pinnacle reef" was higher during daytime than at nighttime. Brunnschweiler and Barnett (2013), conclude that bull sharks move during the daytime at a local scale mainly for feeding purposes, utilizing different coastal habitats based on the different times of the day.

All the sharks tagged in this study were females, no males were observed during the dives for tagging. Local divers reported the presence of mostly females in the study area and they observed some of them with scars from bites along their body's sides (Fig. 4), and in few occasions, divers have reported a chasing behavior of male individuals to females. At the same time, cleaner fishes around rocky reefs are constantly observed in San Pedrillo dive site (pers. comm. Vallejos E., Rojas E., Berrocal D., 2019). 


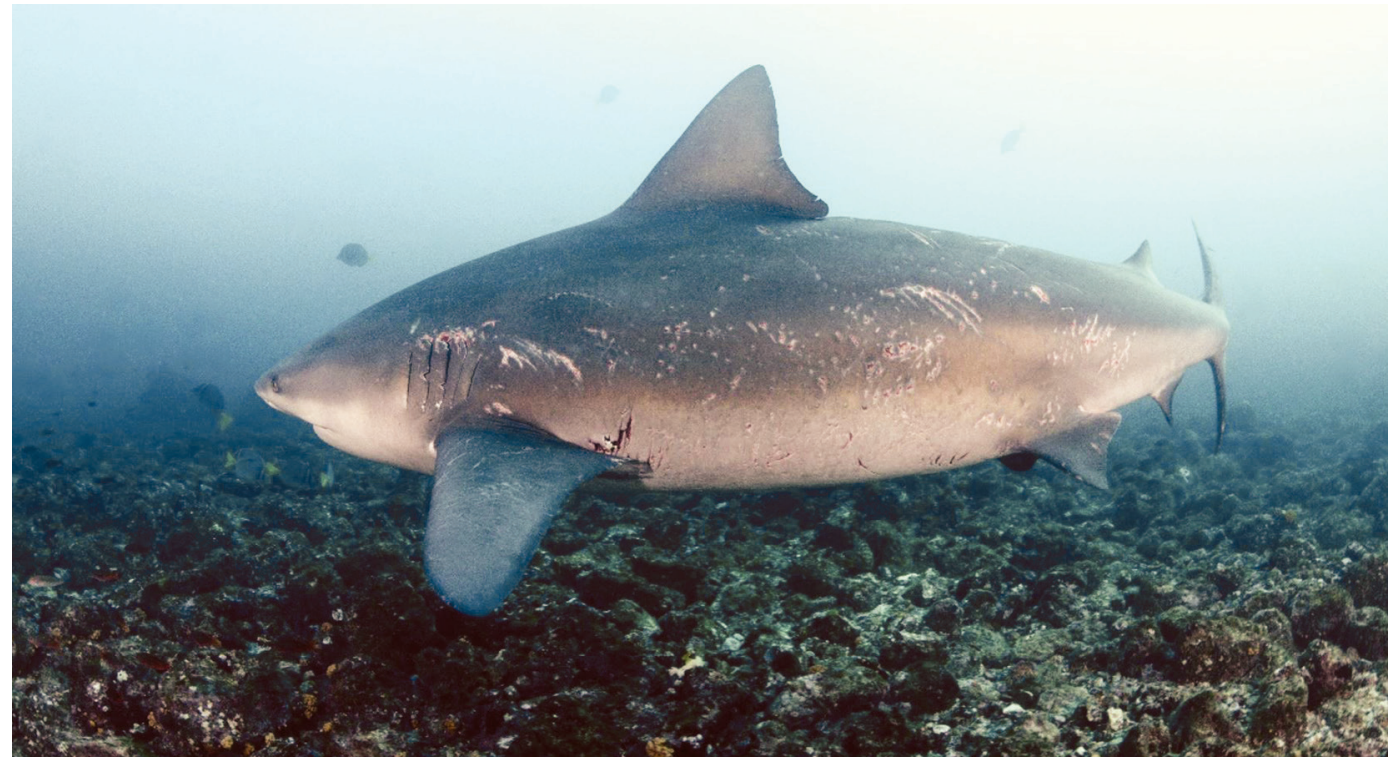

Fig. 4. Bull shark (Carcharhinus leucas) female with bite scars observed at San Pedrillo, Islas Murciélago, Costa Rica. Photography credit: Daniel Berrocal, Okeanos Aggressor.

In Costa Rica, aggregations of sharks' adult females were reported for the scalloped hammerhead shark (Sphyrna lewini) in the oceanic Isla del Coco (Cocos Island), where the sharks aggregate in specific cleaning stations (Nalesso et al. 2019). Nalesso et al. (2019) concluded that the scalloped hammerhead sharks in Isla del Coco were more resident compared with other oceanic islands $(\mathrm{RI}=0.52 \pm 0.31)$, demonstrating that the sharks are strongly associated with that island. The residence of the bull shark $(\mathrm{RI}=0.77 \pm 0.21)$ in San Pedrillo suggests that the site is an important aggregation site for the species. The values of RI (0.441.00 ) reported in this study are higher than the reported for "Pinnacle reef" in Mozambique, where the sharks showed an RI influenced by different factors such as reproductive activity, environmental fluctuations, prey availability, among others (Daly et al., 2014).

We concluded that San Pedrillo is a temporary residence for the bull shark, and it is an important aggregation site related to reproduction, not feeding behaviors. It is also important to highlight that diving activities at San Pedrillo are carried out during the day (between
8:00 and 12:00) in the rainy season when environmental conditions allow the arrival of tourist boats to the site. The higher detection of bull sharks during daytime hours and their interaction with recreational divers makes it necessary to promote good practices for recreational diving in San Pedrillo. At the moment, no shark attacks have occurred at the study site, but it has already been shown that the greatest impact between divers and bull shark occurs when divers perform irresponsible practices (Pasos-Acuña, 2018).

San Pedrillo islet is a critical site for the bull shark, however, more studies are needed to identify feeding and nursery grounds in the Guanacaste Conservation Area and surrounding areas. The identification and protection of critical habitats for this iconic species will bring environmental and social-economic benefits to local communities of Guanacaste.

\section{Management recommendations}

1. Long residence periods of bull sharks in the islet of San Pedrillo, as well as their local migrations, make them a vulnerable 
species to fishing pressures and habitat loss. Therefore, we recommend increasing conservation and protection efforts at Islas Murciélago, especially at San Pedrillo, a site considered essential and critical for the species.

2. It is important to expand the knowledge and understanding of bull shark habitat use in San Pedrillo. Efforts should also focus on the identification of nursery and feeding grounds for the creation of effective conservation measures that guarantee the protection of the species during all its life cycle. The boundary of the MPA is located less than $2 \mathrm{~km}$ from San Pedrillo, therefore, we recommend the creation of a buffer zone to decrease the impact of fisheries on the species. The bull shark is a top predator and an umbrella species, the conservation of its critical habitats will improve the protection of other marine species.

3. Its urgent to involve local communities in the protection of bull sharks through the implementation of training and educational environmental programs. The protection of the species will bring environmental and socio-economic benefits to the local communities that base their economy on tourism.

4. Demonstrating the socio-economic benefits of bull shark conservation will be essential to improve the involvement of local stakeholders and governmental institutions, thus is necessary to estimate the economic value that bull sharks represent to the local communities, especially for Playas de Coco and Cuajiniquil.

Ethical statement: authors declare that they all agree with this publication and made significant contributions; that there is no conflict of interest of any kind; and that we followed all pertinent ethical and legal procedures and requirements. All financial sources are fully and clearly stated in the acknowledgements section. A signed document has been filed in the journal archives.

\section{ACKNOWLEDGMENTS}

The study was successfully carried out thanks to the collaboration and support of various organizations, institutions, divers, and ocean lovers. Thanks to the team of Seamaster Costa Rica, (especially to Cristiano Paoli for helping during the tagging), Área de Conservación Guanacaste (ACG, Guanacaste Conservation Area), Carlos Hiller Submarine Arts, Fallas family, Consorcio Primos Titin, Veerle Roelandt, and Rufford Small Grants.

\section{RESUMEN}

\section{Residencia del tiburón toro, Carcharhinus leucas, (Carcharhiniformes: Carcharhinidae) en el islote de San Pedrillo, Islas Murciélago, Pacífico Norte de Costa Rica}

Introducción: El tiburón toro (Carcharhinus leucas) es una especie tropical y subtropical que habita ríos, estuarios y aguas costeras.

Objetivo: Estudiar la residencia del tiburón toro en San Perdillo, Islas Murciélago, Área de Conservación Guanacaste.

Métodos: Durante el período de estudio (junio de 2013 a febrero de 2015) se marcaron 10 tiburones toro con telemetría acústica en San Pedrillo.

Resultados: los tiburones marcados fueron todos hembras y fueron detectados en 59798 ocasiones por el receptor acústico desplegado en San Pedrillo. Las señales acústicas de los tiburones marcados se recibieron durante un período total de 1 a 229 días (media $=73.9 \pm 71.3$ días), y las últimas detecciones ocurrieron el 9 de enero de 2015 . El índice de residencia de cada tiburón marcado durante todo el período de seguimiento osciló entre 0.41 y 1.00 . La actividad del tiburón toro mostró un patrón significativo a lo largo del día en el receptor que se corresponde específicamente con el ciclo de luz diario.

Conclusiones: Este estudio concluyó que San Pedrillo es un sitio de agregación (estación de limpieza) para el tiburón toro, posiblemente relacionado con comportamientos de reproducción y no de alimentación; y es un sitio crítico para la especie. Se necesitan más estudios para identificar áreas de alimentación y cría en el Área de Conservación de Guanacaste y áreas circundantes.

Palabras clave: Carcharhinus leucas; Guanacaste; marcaje acústico; telemetría pasiva; sitio de agregación.

\section{REFERENCES}

Acuña, D., Smith, A. N. H., Hammerschlag, N., Hearn, A., Anderson, M. J., Calich, H., ... Salinas de León, P. (2017). Residency and movement patterns of an apex 
predatory shark (Galeocerdo cuvier) at the Galapagos Marine Reserve. PLoS ONE, 12(8), e0183669.

Alfaro, E. J., Cortés, J., Alvarado, J., Jiménez, C., Sánchez, C., Nivia, J., León, A., \& Ruiz, E. (2012). Clima y temperatura sub-superfical del mar en Bahía Culebra, Costa Rica. Revista de Biología Tropical, 60(Supplement 2), S159-S171.

Almeida, O. T, McGrath, D. G., \& Ruffino, M. L. (2001). The commercial fisheries of the lower Amazon: an economic analysis. Fish Management Ecology, 8, 253-269.

Amador, J. A., Alfaro, E. J., Lizano, O. G., \& Magaña, V. O. (2006). Atmospheric forcing in the Eastern Tropical Pacific: A review. Progress In Oceanography, 69(2), 101-142.

Bangley, C., Paramore, L., Shifman, D., \& Rulifson, R. A. (2018). Increased abundance and nursery habitat use of the bull shark (Carcharhinus leucas) in response to a changing environment in a warm-temperate estuary. Scientific Reports, 8, 6018.

Barnett, A., Abrantes, K. G, Seymour, J., \& Fitzpatrick, R. (2012). Residency and spatial use by reef sharks of an isolated seamount and its implications for conservation. PLOS ONE ,7(5), e36574.

Brunnschweiler, J. M., \& Barnett, A. (2013). Opportunistic visitors: long-term behavioral response of bull sharks to food provisioning in Fiji. PLoS ONE, 8(3), e58522.

Brunnschweiler, J. M., Queiroz, N., \& Sims, D. W. (2010). Oceans apart? Short-term movements and behavior of adult bull sharks Carcharhinus leucas in Atlantic and Pacific Oceans determined from pop-off satellite archival tagging. Journal of Fish Biology, 77, 1343-1358.

Carlson, J. K., Ribera, M. M., Conrath, C. L., Heupel, M. R., \& Burgess, G. H. (2010). Habitat use and movement patterns of bull sharks Carcharhinus leucas determined using pop-up satellite archival tags. Journal of Fish Biology, 77, 661-675.

Cisneros, A. M., Barnes M., Navarro E., \& Rashidsumaila, U. (2013). Global economic value of shark ecotourism: implications for conservation. Oryx, 47(3), 381-388.

Cruz-Martínez, A., Chiappa-Carrara, X., \& Arenas-Fuentes, V. (2004). Age and growth of the bull shark, Carcharhinus leucas, from southern Gulf of Mexico. Journal of Northwest Atlantic Fishery Science, 37, 367-374.

Compagno, L. J. V. (1984). FAO: Species Catalog Vol 4: Sharks of the World. An Annotated and Illustrated of Sharks Species Know to Date. Part 1 and 2. FAO Fish Synopsis, 125 .
Curtis, T. H., Adams, D. H., \& Burgess, G. H. (2011). Seasonal distribution and habitat associations of bull sharks in the Indian River Lagoon, Florida: A 30-year synthesis. Transactions of the American Fisheries Society, 140, 1213-1226.

Curtis, T., Parkyn, D., \& Burgess, G. (2013). Use of human-altered habitats by bull sharks in a Florida nursery area. Marine and Coastal Fisheries: Dynamics Management and Ecosystem Science, 5, 28-38.

Daly, R., Smale, M. J., Cowley, P. D., \& Froneman, P. W. (2014). Residency patterns and migration dynamics of adult bull sharks (Carcharhinus leucas) on the East coast of southern Africa. PLoS ONE, 9(10), e10935.

Davis, G., \& Klapfer, A. (2018). Costa Rica Blue: The Underwater Guide. San José, Costa Rica: Blue Publishing, S.A.

Denyer, P., Cortés, J., \& Cárdenes, G. (2005). Hallazgo de dunas fósiles de final del Pleistoceno en las Islas Murciélago, Costa Rica. Revista Geológica de América Central, 33, 29-44.

Espinoza, M., Farrugia, T. J., \& Lowe, C.G. (2011) Habitat use, movements and site fidelity of the gray smoothhound shark (Mustelus californicus, Gill 1863) in a newly restored southern California estuary. Journal of Experimental Marine Biology and Ecology, 401, 63-74.

Garla, R. C., Chapman, D., Shivji, M. S., Wetherbeed, B. M., \& Amorim, A. F. (2006). Habitat of juvenile Caribbean reef sharks, Carcharhinus perezi, at two oceanic insular marine protected areas in the southwestern Atlantic Ocean: Fernando de Noronha Archipelago and Atol das Rocas, Brazil. Fisheries Research, 81, 236-241.

Graham, F., Rynne, P., Estevanez, M., Luo, J., Ault, J., \& Hammerschlag, N. (2016). Use of marine protected areas and exclusive economic zones in the subtropical western North Atlantic Ocean by large highly mobile sharks. Diversity and Distributions, 22, 534-546.

Heupel, M. R., Simpfendorfer, C. H., Espinoza, M., Smoothey, A. F., Tobin, A., \& Peddemors, V. (2015). Conservation challenges of sharks with continental scale migrations. Frontiers in Marine Science, 2, 12. https://doi.org/10.3389/fmars.2015.00012

InfoStat (2008). InfoStat, versión 2008. Manual del Usuario. Grupo InfoStat, FCA, Universidad Nacional de Córdoba. Argentina: Editorial Brujas Argentina.

Jenson, N. H. (1976). Reproduction of the bull shark, Carcharhinus leucas, in the Lake Nicaragua-Rio San Juan System. Investigations of the Ichthyofauna of Nicaraguan Lakes, 40, 539-559.

Jiménez, J. A. (2016). El Domo Térmico de Costa Rica: Un oasis de productividad frente a las costas del Pacifico 
Centroaméricano. San José, Costa Rica: Fundación MarViva.

Lizano, O., \& Alfaro, E. (2015). Dinámica atmosférica y oceánica en algunos sitios del Área de Conservación Guanacaste (ACG), Costa Rica. Revista de Biología Tropical, 62(Supplement 4), S17-S31.

López, A., Arauz, R., Zanella, I., \& Le Foulge, L. (2009). Análisis anual de las capturas de tiburones y rayas en las pesquerías artesanales de Tárcoles, Pacífico Central de Costa Rica. Revista Ciencias Marinas y Costeras, 1, 145-157.

López, A., \& Zanella, I. (2015). Tiburones y rayas capturados por pesquerías artesanales con línea de fondo en el Golfo Dulce, Costa Rica. Revista Biología Tropical, 63(Supplement 1), 183-198.

McDavitt, M. T. (2002). Lake Nicaragua revisited: conversations with a former sawfish fisherman. Shark News: Newsletter of the IUCN Shark Specialist Group, 14, 5.

Niella, Y., Afonso, A. S., \& Hazin, F. H. (2017). Bioecology and movements of bull sharks, Carcharhinus leucas, caught in a long-term longline survey off northeastern Brazil. Neotropical Ichthyology, 15(3), e170106.

Pasos-Acuña, C. (2018) Efecto del buceo en el comportamiento del tiburón toro (Carcharhinus leucas) y evaluación económica de la especie en el Parque Nacional Cabo Pulmo (Master's thesis). Centro de Investigaciones Biológicas del Noroeste, S.C., La Paz, Baja California, México.

Powers, S. P., Fodrie, F. J., Scyphers, S. B, Drymon, J. M., Shipp, R. L., \& Stunz, G.W. (2013). Gulf-wide decreases in the size of large coastal sharks documented by generations of fishermen. Marine and Coastal Fisheries: Dynamics, Management, and Ecosystem Science, 5, 93-102.

Papastamatiou, Y., Friedlander, A., Caselle, J., \& Lowe, C. (2010). Long-term movement patterns and trophic ecology of blacktip reef sharks (Carcharhinus melanopterus) at Palmyra atoll. Journal of Experimental Marine Biology and Ecology, 386(1-2), 94-102.

R Development Core Team R. (2014). R: A Language and Environment for Statistical Computing. Vienna, Austria: R Foundation for Statistical Computing. http:// www.R-project.org/

Rodríguez, A., Alfaro, E. J., \& Cortés, J. (2021). Spatial and temporal dynamics of the hydrology at Salinas Bay, Costa Rica, Eastern Tropical Pacific. Revista de Biología Tropical, 69(Suppl. 2), S105-S126.

Simpfendorfer, C. A, Greitas, G. G., Wiley, T. R., \& Heupel, M. R. (2005) Distribution and habitat partitioning of immature bull sharks (Carcharhinus leucas) in a southwest Florida estuary. Estuaries, 28, 78-85.

SINAC (Sistema Nacional de Áreas de Conservación). (2013). Plan de Manejo Área de Conservación Guanacaste 2014-2024. Guanacaste, Costa Rica: Área de Conservación Guanacaste.

Thorson, T. B. (1971). Movement of bull sharks, Carcharhinus leucas, between Caribbean Sea and Lake Nicaragua demonstrated by tagging. Copeia, 1971, 336-338.

Thorson, T. B. (1972). The status of the bull shark, Carcharhinus leucas, in the Amazon River. Copeia, 1972, 601-605.

Thorson, T. B. (1982). The impact of commercial exploitation on sawfish and shark populations in Lake Nicaragua. Fisheries, 7, 2-10.

Werry, J. M., \& Clua, E. (2013). Sex-based spatial segregation of adult bull sharks, Carcharhinus leucas, in the New Caledonian great lagoon. Aquatic Living Resources, 26, 281-288.

Zanella, I., López, A., \& Cure, K. (2019). Golfo Dulce: critical habitat and nursery area for juvenile scalloped hammerhead sharks Sphyrna lewini in the Eastern Tropical Pacific Seascape. Environmental Biology of Fishes, 102, 1291-1300. 